\title{
VERSLUMO UGDYMO IMITACINĖSE BENDROVĖSE EFEKTYVUMO DIDINIMAS, TAIKANT DALYKŲ INTEGRACIJĄ
}

\author{
Asta Pancerovienè, lektorè, Verslo fakulteto dekanè \\ Adele Stoniene, lektoré \\ Vida Žviniené, lektoré \\ Klaipédos valstybine kolegija \\ DOI: https://doi.org/10.52320/svv.v0iVI.200
}

\begin{abstract}
Anotacija
2019 - 2021 metais atliktas Lietuvos imitaciniu bendrovių asociacijos užsakytas tyrimas, kurio tikslas buvo atskleisti verslumo ugdymo imitacinèse bendrovėse efektyvumo didinimo galimybes, taikant dalykų integravimą. Tyrimo metodai: analitinè mokslinès literatūros analizè, kiekybinè reprezentatyvi apklausa raštu, statistinè duomenu analizè. Remiantis mokslinès literatūros šaltinių analize, atskleista dalykų integravimo nauda studijų/mokymo procesui. Išanalizavus dalykų integravimo galimybes i IB veiklą, nustatyta, kad dauguma respondentų atsakè, kad jų galima dèstomo/mokomo dalyko integracija ị IB veiklą integruotųsi integruotu mokymo lygiu, kai pasirenkama tema apima visas arba daugelį disciplinų. IB veikla apima labai platų iggtų teorinių žinių pritaikomumą praktinèje veikloje, todèl integruojant dalykus integruotu mokymo lygiu rengiant bendras praktines užduotis, būtu aiškesnès tarpdalykinių ryšių sąsajos.

Analizuojant verslumo ugdymo efektyvumo didinimo būdus, taikant dalykų integravimą IB veikloje, buvo išsiaiškinta, kad reikètų skatinti dėstytojų/ mokytojų tarpusavio bendradarbiavimą, atnaujinant studijų programas, rengiant metodinę medžiagą ir bendras praktines užduotis, reikètų įtraukti darbdavius ir socialinius partnerius, lankytis tikrose verslo i̇monèse ar kviesti verslo atstovus ị paskaitas/pamokas ir nagrinèti praktines situacijas. Būtu galima pasiūlyti mokymo institucijose kurti bendrą su kitais dalykais integruotą virtualią aplinką, kurioje būtų pateikiama metodinè medžiaga, integruotos užduotys, bendradarbiavimo ir vertinimo priemonių sistema, leidžianti lanksčiai valdyti integruotą studiju procesą, siekiant gerinti mokymosi kokybę, orientuotą ị platesnį žinių panaudojimą.
\end{abstract}

Pagrindiniai žodžiai: verslumas, imitacinè bendrovè, dalykų integravimas.

\section{Ivadas}

Temos aktualumas. Visuomenëje vyrauja tendencijos, jog pradèti savo verslą, ar kilti karjeros laiptais - labai sunku ir rizikinga. Taip yra dèl ekonominio nestabilumo (ypač pandemijos sąlygomis), tačiau didžiausia problema, žmonių nesugebejjimas tobulèti, prisiimti atsakomybę, bei neturejjimas tinkamų žinių. Jauno žmogaus profesiniame kryptingume svarbiausia yra teorines žinias pritaikyti praktikoje, tačiau kur atrasti tokią vietą, dar nepatyrusiam, bet ambicingam žmogui. Tuo tikslu, Lietuvoje buvo ikurtos imitacinès bendrovès (toliau tekste IB), kurių veiklą koordinuoja Lietuvos imitacinių bendrovių asociacija (toliau LIBA) kartu su „Simulith“ centru, kuris yra „PEN Worldwide“ pasaulinès nacionalinių tinklų asociacijos narys. Studentai IB dirba antrame kurse, kai jau yra nemažai išklausę specialybinių dalykų, o kai kuriuos studijuoja lygiagrečiai. Dirbdami IB jie gali studijų dalykus integruoti - sujungti ị visumą, kuriant naują mokymo turinio jungtị IB bei ugdydami verslumo igūdžius tiek Lietuvos, tiek užsienio rinkose veikiančiose imitacinèse bendrovėse.

Tyrimo problema. Integruotas dalykų ugdymas, sudaro galimybes pasireikšti intelekto daugialypiškumui, kartu sukuria prielaidas visiems dalykams tapti jungiamaja ugdymo grandimi. Lietuvos imitacinių bendrovių asociacija įžvelgia, kad pagrindinè tokio ugdymo grandis galètų būti Lietuvoje veikiančios imitacinès bendrovès, tačiau nėra įvertinta, kokios didaktinès priemonès ir mokymo/si strategijos šioje veikloje galètų būti taikomos dažniausiai ir yra priimtiniausios.

Tyrimo objektas - dalykų integravimas imitacinių bendrovių veikloje.

Tyrimo tikslas - atskleisti verslumo ugdymo imitacinèse bendrovėse efektyvumo didinimo galimybes, taikant dalykų integravimą.

\section{Tyrimo uždaviniai:}

1. Atskleisti dalykų integravimo teorinius modelius.

2. Nustatyti dalykų integravimo galimybes i IB veiklą.

3. Ivertinti dalykų integravimo privalumus IB veikloje.

4. Nustatyti verslumo ugdymo efektyvumo didinimo būdus, taikant dalykų integravimą IB veikloje. 
Tyrimo metodai: analitinè mokslinès literatūros analizè, kiekybinè reprezentatyvi apklausa raštu, statistinè duomenų analizè.

\section{Dalykų integravimo teoriniai modeliai}

Ugdymo turinio integravimas tampa vis svarbesniu reiškiniu šiandieniniame švietimo sistemos kaitos procese. Integruotas ugdymas yra prasmingas, kuomet mokomieji dalykai integruojami atsižvelgiant ị daugialypę intelekto struktūrą ir dalykų tarpusavio integralumą. Integruotas ugdymas, sudarantis galimybes pasireikšti intelekto daugialypiškumui kartu sukuria prielaidas visiems dalykams tapti jungiamaja ugdymo grandimi. Jis įkūnija tokias vertybes, kaip kritiškas mąstymas, intelektualinė branda, mokinių ir mokytojų bendradarbiavimas. Integruotas ugdymas leidžia matyti disciplinų ribas, ryšius tarp jų, vadinasi, sudaro prielaidas ịvertinti savo kompetencijos ribas ir rasti būdus turimam žinių lygiui praplèsti (Junevičienè, 2011).

Dabartinis lietuvių kalbos žodynas integraciją (lot. integratio - atnaujinimas, atstatymas) aiškina taip: „,integracija - jungimasis ị visumą“.

Integruotos mokymo programos igyvendinimas yra sudètingas procesas. Natūralu, kad kyla klausimas: kuo naudingas integruotas mokymasis ir kokios yra sėkmingo igyvendinimo prielaido? Svarbiausia sėkmès prielaida yra mokymosi filosofijos suvokimas, protinga metodika bei suprantama igyvendinimo strategija. Pirmiausiai patys programų kūrèjai turi suprasti integruotos ugdymo programos prasmę, išstudijuoti specifines jos kūrimo ypatybes ir tik tuomet ịtraukti mokytojus i planavimo procesą. Lengviau yra didinti integruotų dalykų skaičių palaipsniui, kai susitariama dèl studijų tikslų, išteklių, apimties, laiko ir kai pateikta programos mokymo medžiaga (Junevicius, Juneviciene, Cepeliauskaite, Daugeliene, 2021).

Integruotas mokymasis igauna vis didesnę reikšmę ir sudaro svarbiausią studijų proceso komponentą profesinèse studijose. Tokia mokymosi patirtis nukreipia studentus/mokinius i profesini pasirengimą darbui ir užtikrina lengvesnị perèjimą iš studijų i veiklos pasaulį, nes padeda ugdyti žinias, ịgūdžius ir gebèjimus, kuriuos sunku puoselèti tik akademinèje aplinkoje.

Integruoto dalyko studijos apima:

- Psichologini poveiki mąstymo gebejjimams ugdyti.

- Emocinę įtaka mąstymui.

- Būdus atminties sustiprinimui ir gerinimui.

- Veiksmingas mokymosi technikas.

- Skaitymo greičio padidinimo būdus.

- Suvokimo tobulinimo būdus apmąstymo prigimtį ir praktinị jo taikymą (Drake, Burns, 2010).

Studijų procese apjungiama teorija ir praktika, tokiu būdu sustiprinamos studijos, studentai/mokiniai analizuoja teorines sąvokas, modelius, remdamiesi patirtimi, igyta kompanijose praktikų metu. Studijų/mokymo programose, kuriose numatyta mokymo ir mokymosi integracija, nurodomi ir planavimo bei organizavimo būdai, atskiri dalykai susiejami tarpdalykiniais ryšiais siekiant efektyvesnių studijų (Junevičienè, 2011).

Kiliuvienė (2002) išskiria išsamiuosius integracinius ryšius, tarpdalykinius ryšius ir vidinę integraciją. Pagal Snyder (1996) išskiriami trys integracijos lygiai: jungimas, koreliacija ir integracija. 


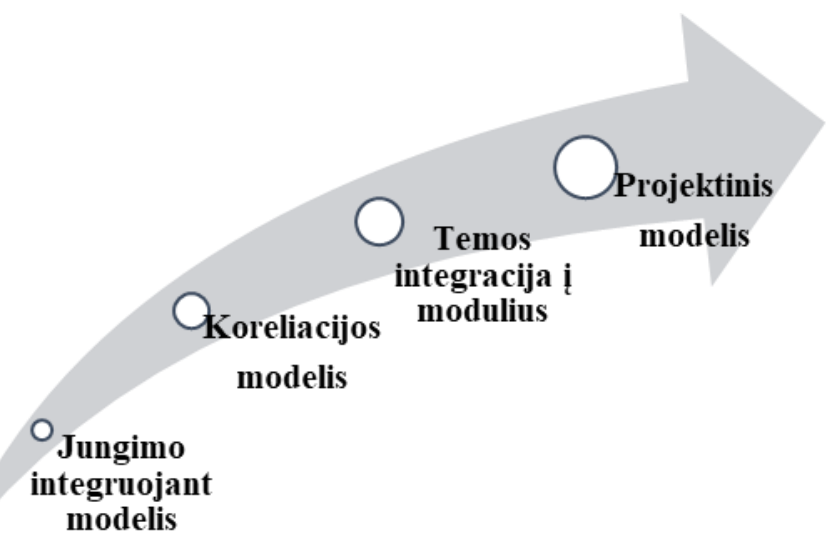

1 pav. Ugdymo turinio integravimo būdai

Šaltinis: Vilkelienė A., 2006. Integruotas ugdymas: disciplinų integralumas nūdienos kontekste.

Jungimo lygyje mokejjimai ir žinios vienoje disciplinoje pritaikomi norint sustiprinti kito dalyko mokymą. Sąvokos ir dalyko medžiaga yra paimamos iš vienos disciplinos, kad padètų mokytis ar sustiprintų kitą discipliną. Tokia integruoto ugdymo pradžia patinka dėstytojams/mokytojams ir studentams/mokiniams, bei padeda siekti naujų tikslų. Tai populiariausias, dažniausiai naudojamas būdas jungti disciplinas.

Antras integracijos lygis - koreliacija. Koreliacija vyksta tarp dviejų dalykų: mokytojai tarpusavyje suderina tam tikras atskiras temas, susipažista su einama medžiaga.

Mokymas vyksta neturint tikslo apibendrintai demonstruoti mokymosi procesą. Koreliacija vyksta tarp dviejų disciplinų ar veiklų. Koreliacija - tai jau antras žingsnis, bylojantis apie įvairių dalykų sujungimą i programas. Dėstytojai/mokytojai stengiasi suprasti vienas kito programą. Taikant koreliaciją dažniau jungiama dalyko esmè (medžiaga), o ne tema.

Integruotas mokymo lygis pasiekiamas, kai mokymo procese studentui/mokiniui sudaroma galimybe panaudoti visas daugialypio intelekto struktūras. Integruojant teminį vienetą, pasirenkama plati tema, kuri integraliai apima visas arba daugelị disciplinų. Tuo siekiama vaikus mokyti lyginimo, analizès, apibendrinimo, platesnio požiūrio ị reiškinius, kritinio mąstymo ( Snyder, 1996).

Pastaraisiais metais labai populiarus projektinis integruoto ugdymo lygmuo. Projektinis ugdymas efektyvus tuomet, kai sprendžiamos vietinio reikšmingumo, atviros problemos. Jo metu išryškèja aktualiausios temos, pademonstruojami subrandinti igūdžiai, atrandamos naujos raiškos formos. Projektinio ugdymo metu pasireiškia ịvairūs integracijos lygiai - nuo paprasto dviejų disciplinų siejimo iki daugelio disciplinų integravimo.

Projektas - tai mokymosi metodas, padedantis teorines žinias pritaikyti praktinèje veikloje. Šis metodas paremtas besimokančiojo praktine veikla. Geoff (2006) pabrěžia, kad taikant projekto metodą, centre yra studento/mokinio veikla, dèstytojas/mokytojas tampa partneriu. „Projektinè veikla skatina ugdymo proceso individualizavimą - padeda $\mathfrak{i}$ mokymo procesą įsitraukti įvairaus charakterio, skirtingo pasirengimo vaikams, leidžia jiems atskleisti savo kūrybinius sugebèjimus, sudaro galimybes kiekvienam besimokančiajam pasijusti gabiam ir „reikšmingam“. Projekto metodas glaudžiai susijęs su problemos iškèlimu ir sprendimo paieškomis bei galutinio rezultato siekimu.

Projekto metodo veiklos gali būti tiek individualios, tiek ir taikomos grupèse. Studentus/mokinius skirstant ị grupes, galima atsižvelgti i jų žinias, ịūdžius, pasirenkamas veiklas. Veikloje sudaromos galimybės aktyviụjų mokymosi metodų sąveikai, pasirenkant kelis ugdymo metodus.

Projekto metodo taikymas yra orientuotas ị aktyvų besimokančiojo dalyvavimą ugdymo veikloje, imantis iniciatyvos, sprendžia problemas, siekia galutinio rezultato.

Junevičienė (2011), pabrèžia dalyvavimo integruoto mokymosi procese galimybes:

- Pritaikyti teoriją praktiškai.

- Apsvarstyti ir plettoti karjeros galimybes.

- Susikurti galimybes dalyvauti veiklos tinkle.

- Vystyti savo gebėjimus mąstyti kūrybiškai ir kritiškai. 
- Suprasti, ko jūs nenorètumète daryti ateityje.

- Išmokti dirbti, kaip dirbama veiklos pasaulyje.

- Vystyti svarbiausius bendruosius gebejjimus, kurių reikalauja darbdaviai.

Informacinių ir komunikacinių technologijų įvairovė, taikoma šiuolaikiniuose mokymo ir mokymosi procesuose, tampa neatsiejama studijų organizavimo dalimi. Pagal informacinių technologijų integravimo lygi i dalyko mokymo procesą paprastai skiriami trys mokymo modeliai: tradicinis (angl. face-to-face), kai mokomasi tam tikru laiku ir numatytoje vietoje, bendraujama tiesiogiai ir informacinès technologijos mokymo procese specialiai netaikomos; nuotolinis mokymas (angl. distance learning), kai visa mokymuisi skirta medžiaga pasiekiama ir studijos organizuojamos bei bendraujama kompiuterių tinklu; mišrus (angl. blended learning), kuriam būdingas tradicinio mokymo auditorijoje derinimas su nuotoliniu mokymusi kompiuterių tinklo aplinkoje (Moore, Kearsley, 2012).

Apibendrinant galime teigti, kad integruoti dalykai leidžia sisteminti informaciją, sieti ją su praktine veikla, didinant besimokančiujų motyvaciją, skatina besimokančiųų ir dėstytojų/mokytojų bendradarbiavimą. Integracija apima visapusišką asmenybès ugdymą ir integruotą mokymą(si), kurio metu panaudojamos skirtingų dalykų žinios, ịvairiais aspektais susijusios su besimokančiojo aplinka. Pagal integruojamų dalykų ryšių sudètingumą išskiriami jungimo, koreliacijos ir integruoto mokymo bei projektinio integruoto ugdymo lygiai.

\section{Dalykų integravimo galimybẻs, ugdant verslumą imitacinėse bendrovėse, tyrimo rezultatụ analizè}

\subsection{Tyrimo metodika}

Tyrimo procesas. Tyrimas buvo vykdomas Asociacijos LIBA užsakymu. Prieš pradedant tyrimą, buvo nuspręsta apklausti IB vadovus bei dėstytojus/mokytojus, dirbančius tose studijų programose, kuriose yra veikiančios IB. Tyrimo pradžioje buvo nuspręsta apklausti apie 30 Lietuvos imitacinių bendrovių vadovų, arba ne mažiau nei 70 proc. Lietuvos tinklo imitacinèse bendrovèse dirbančių vadovų. Šiuo metu veikia 40 imitacinių bendrovių, 70 proc. sudaro 28 imitacinès bendrovès ir dar dvigubai daugiau dėstytojų /mokytojų, dirbančių tose studijų programose, kuriose yra veikiančios IB. Buvo siekta apklausti 84 respondentus, o atsakymų sulaukta iš 81 respondento.

Tyrimo eiga. Tyrimas vyko 2019-2021 metais. $2019 \mathrm{~m}$. buvo parengtas tyrimo klausimynas, tyrimo metodika, tyrimo atlikimo kalendorius. Vykdant apklausą buvo sukurtas elektroninis tyrimo klausimynas ir išsiųstas kvietimas - prašymas dalyvauti tyrime. $2020 \mathrm{~m}$. sausio - birželio mèn. buvo vykdoma apklausa, kuri, nesurinkus pakankamo respondentų kiekio, $2020 \mathrm{~m}$. rugsèjo- lapkričio mèn. buvo pratęsta. $2021 \mathrm{~m}$. sausio-kovo mèn. buvo analizuojami tyrimo rezultatai, parengta tyrimo ataskaita.

Tiriamuju atranka - respondentams atrinkti naudojama netikimybinè kriterinè atranka (Valackienè, Mikènè, 2008; Kardelis, 2009; Bryman, 2016).

Apklausos metodas - anketinè apklausa, naudojant iš anksto parengtą standartizuotą klausimyną, kuris sudarytas tyrimo autorių. Klausimyną sudarė demografiniai klausimai ir teiginiai, kuriais buvo siekiama įvertinti dalykų integravimo galimybes, ugdant verslumą imitacinèse bendrovèse.

\section{Kokybès kontrolè:}

- vidinis tyrimo atlikimo patikrinimas: 100 proc. kontrolè (anketos užpildymo pilnumas, apklausos nuoseklumas);

- išorinis tyrimo atlikimo patikrinimas: apklausa vykdoma laikantis metodinių reikalavimų; nepažeistas respondentų atrankos principas;

- duomenų ịvedimo kontrolè: tikrinama mažiausiai 20 proc. ịvesto duomenų masyvo.

Tyrimo etika. Tyrimo metu buvo laikomasi tyrimo etikos principų: apsaugos, slaptumo (anonimiškumo ir konfidencialumo), geranoriškumo, universalumo, reikšmingumo, pagarbos asmens orumui, teisingumo bei teisès gauti tikslią informaciją (Bitinas, Rupšienė, Žydžiūnaitè, 2008; Kardelis, 
2009; May, 2011 ir kt.). Tyrimas buvo atliekamas remiantis laisvanoriškumo principu. Atliekant tyrimą, svarbiausi buvo šie etikos principai, kurių ir laikytasi (Gaižauskienè, Valavičienè, 2016):

- Gerbti tyrimo dalyvių nepriklausomybę, laisvę, t.y., pasirinkti dalyvauti arba atsisakyti dalyvauti tyrime.

- Tyrimo dalyviui suteikti kuo išsamesnès informacijos apie tyrimo esmę ir tikslą.

- Tyrimo dalyvių anonimiškumo išsaugojimas, užtikrinant konfidencialumą ir privatumą.

Tyrimo etika numato šio tyrimo bendrai priimtinus dalykus (imties dydis, imties atranka, duomenų rinkimas, apibendrinimas ir kt.), kurie paskatino apsvarstyti visos tyrimo eigos alternatyvas, numatant jų stipriąsias ir silpnąsias puses bei pasirinkti tinkamiausią tyrimo eigą.

Tyrimo duomenų analizė: Grafinè analizė atlikta naudojantis „Anketa.lt“ surinktais duomeninis bei Ms Excel skaičiuokle.

\subsection{Dalykų integravimo galimybès, ugdant verslumą imitacinėse bendrovèse}

Imitacinė bendrovė (iki 2016 metų vadinta Verslo praktinio mokymo firma arba VPM firma) ivvairiose institucijose verslo mokymo tikslais nuolat veikianti bendrovė, veiklą vykdanti uždarame imitacinių bendrovių pasauliniame tinkle. Ši bendrovè yra praktinio mokymo priemonè ir vieta jos praktikantams dirbti ir mokytis. Jai vadovaujama kaip tikrai verslo įmonei su realia jos verslo vystymo tvarka, produktais ir paslaugomis, naudojant visus dokumentus, procedūras ir programas, kurių reikia norint valdyti verslą, laikantis nacionalinių ekonomikos taisyklių ir teisès aktų, tačiau nenaudojant realių pinigų ir prekių. Taip lavinami igūdžiai, kuriuos turèdami praktikantai igyja daugiau galimybių ịsidarbinti. IB gali būti suformuota beveik visų rūšių verslui plètoti: nuo didmeninès iki mažmeninès prekybos, paslaugų teikimo, ìvairių produktų rinkodaros ir gamybos. Yra daug ịvairiose srityse veikiančių pavyzdžių: informacinių technologijų ir elektronikos, bankininkystès ir mados, reklamos ir turizmo, amatų ir t. t. srityse. Daugeliu atveju jos taikosi prie vietos rinkos poreikių ir ieško realių verslo rėmèjų arba partnerinių i̇monių. IB tikslas - suteikti praktikantams verslo žinių, formuoti ir įtvirtinti verslo ịgūdžius, sudarant sąlygas teorines žinias taikyti praktiškai, prekiaujant tarpusavyje per Simulith tinklą Lietuvoje (vienija apie 40 bendrovių) ir EUROPEN - PEN International asociaciją visame pasaulyje (vienija apie 7200 bendrovių). „Simulith“ centras yra vienintelis, unikalus imitacinių bendrovių centras Lietuvoje, koordinuojantis imitacinių bendrovių veiklą visos IB yra puiki galimybė išbandyti save imitacinejje įmonèje ir sužinoti kaip jos veikia, nes tai yra tikra ịmonè. Atliekant praktiką tokioje bendroveje studentams yra puiki galimybė išbandyti tikrą verslą, įvertinti individualų ir komandinị darbą.

Dirbant IB teorinès žinios pritaikomos praktiškai, todèl atsiranda galimybė atskirus dalykus susieti tarpdalykiniais ryšiais bei integruoti i IB veiklą.

Siekiant nustatyti studijų/mokslo dalykų integravimo galimybes ị IB veiklą, respondentams buvo užduotas klausimas, kuriuo lygiu įmanoma jūsų dėstomo/ mokomo dalyko integracija ị IB veiklą? Atsakymų suvestinè pateikta 2 pav.

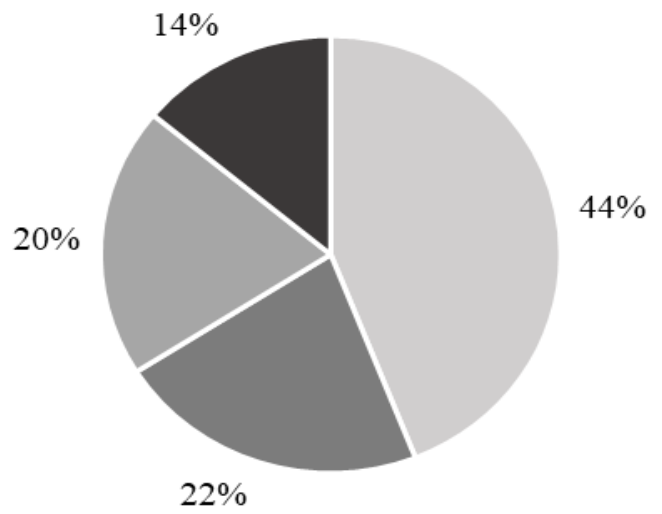

\footnotetext{
- Integruotas mokymo lygis, kai pasirenkama tema apimanti visas arba daugelị disciplinų.

- Koreliacijos lygis, kai integruojami giminiškos srities dalykais.

- Projektinis integruoto ugdymo lygis, kai destomi dalykai pasitelkiami problemai spręsti.

- Jungimo lygis, kai kitas dalykas netiesiogiai padeda mokyti/s.
}

2 pav. Dėstomo/ mokomo dalyko integracijos lygiai ị IB veiklą, proc.

Šaltinis: sudaryta autorių pagal tyrimo duomenis, 2020. 
Kaip matome 2 pav., 44 proc. respondentų atsakè, kad jų dėstomo/mokomo dalyko integracija i IB veiklą integruotųsi integruotu mokymo lygiu, kai pasirenkama tema apima visas arba daugeli disciplinų. 22 proc. respondentų teigia, kad koreliacijos lygiu, kai integruojami giminiškos srities dalykai, 20 proc. respondentų atsako, kad projektinio integruoto ugdymo lygiu, kai dèstomi dalykai pasitelkiami problemai spręsti, o 14 proc. pirmenybę teikia jungimo lygiui, kai kitas dalykas netiesiogiai padeda mokyti/s.

Sekančiu klausimu buvo prašyta pažymèti ir įvertinti, kuriems teiginiams apie integruoto mokymo privalumus respondentai pritaria, kai galvoja apie savo desstomo/ mokomo dalyko integraciją i IB veiklą? Buvo vertinama nuo 1 iki 5, kai 1 - visiškai nepritariu, 5 - visiškai pritariu (3 pav.).

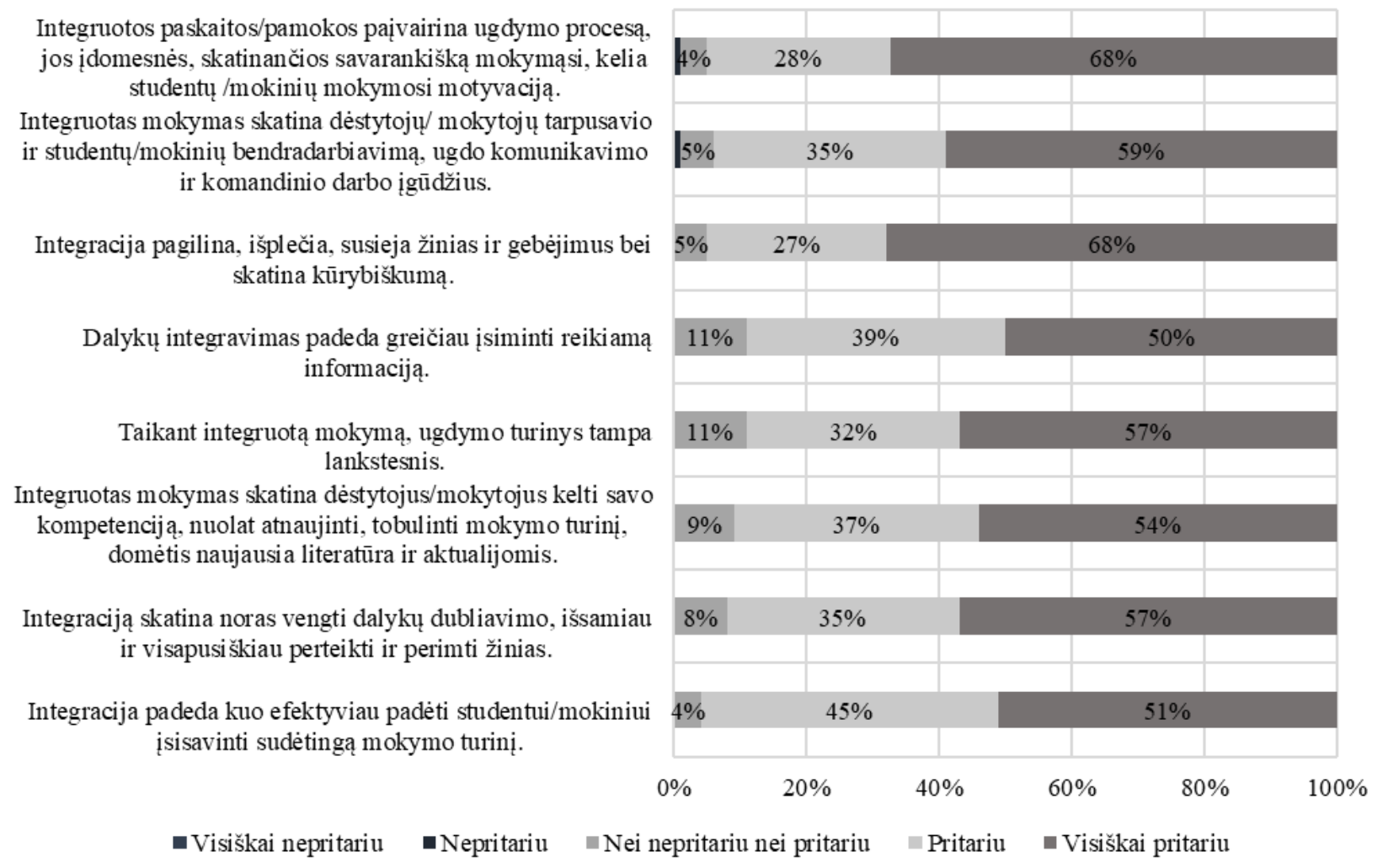

3 pav. Integruoto mokymo privalumų vertinimas apie respondentų dėstomo/ mokomo dalyko integraciją ị IB veiklą, proc.

Šaltinis: sudaryta autorių pagal tyrimo duomenis, 2020.

Dauguma respondentų nuo 96 proc. pritaria arba visiškai pritaria teiginiams, kad Integruotos paskaitos/pamokos paịvairina ugdymo procesą, jos įdomesnès, skatinančios savarankišką mokymąsi, kelia studentų /mokinių mokymosi motyvaciją; integruotas mokymas skatina dèstytojų/ mokytojų tarpusavio ir studentų/mokinių bendradarbiavimą, ugdo komunikavimo ir komandinio darbo igūdžius; integracija pagilina, išplečia, susieja žinias ir gebejjimus bei skatina kūrybiškumą; integracija padeda kuo efektyviau padèti studentui/mokiniui įsisavinti sudètingą mokymo turinị. 11 proc. apklaustujų nei pritaria, nei nepritaria teiginiams, kad dalykų integravimas padeda greičiau ịsiminti reikiamą informaciją; kad taikant integruotą mokymą, ugdymo turinys tampa lankstesnis, nors 89 proc. šiems teiginiams pritaria arba visiškai pritaria. 8-9 proc. respondentų nei pritaria nei nepritaria teiginiams, kad integraciją skatina noras vengti dalykų dubliavimo, išsamiau ir visapusiškiau perteikti ir perimti žinias, kad integruotas mokymas skatina dėstytojus/mokytojus kelti savo kompetenciją, nuolat atnaujinti, tobulinti mokymo turini, domètis naujausia literatūra ir aktualijomis, nors 91-92 proc. jiems pritaria.

Apibendrinant galima teigti, kad galvojant apie respondentų dėstomo/ mokomo dalyko integraciją i IB veiklą, daugumai integruoto mokymo privalumų teiginių buvo vertinti pritarimu arba visišku pritarimu. 
Tyrimo eigoje buvo siekiama išsiaiškinti, kokie yra respondentų dėstomi/mokomi dalykai, kurie galètų būti integruoti ị IB veiklą? (4 pav.).

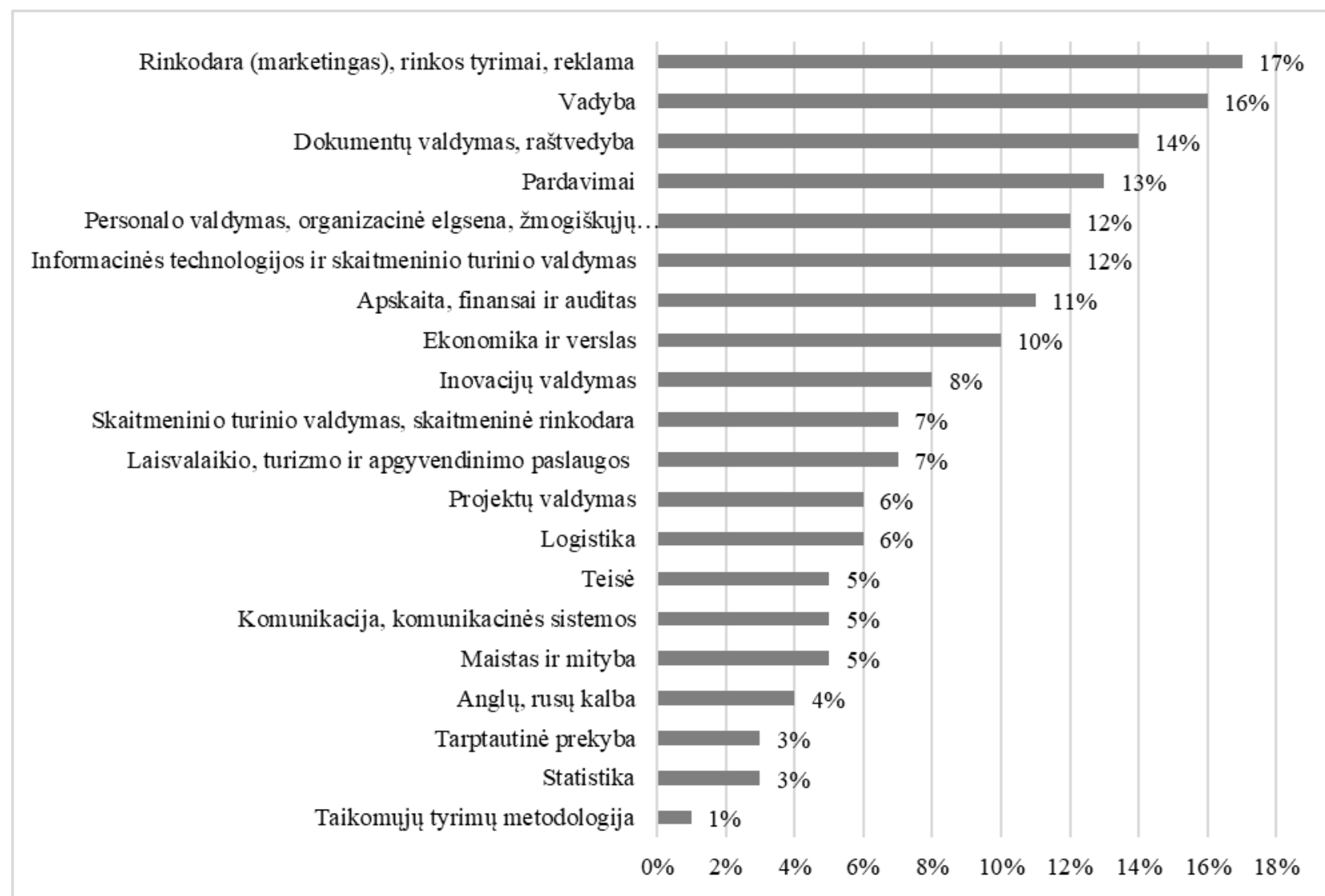

4 pav. Respondentų dèstomi/mokomi dalykai, kurie galètų būti integruoti ị IB veiklą

Šaltinis: sudaryta autorių pagal tyrimo duomenis, 2020

Tyrimo metu buvo siekiama įsigilinti i integruoto mokymo patirtic, todèl buvo paprašyta respondentų, parašyti savo ịžvalgas apie integruoto mokymo privalumus, kai galvoja apie jų dèstomo/ mokomo dalyko integraciją i IB veiklą. Atsakymų buvo ịvairių:

- skatinamas bendradarbiavimą bei mokymosi motyvacija;

- pasiekiami geresni studijų programos rezultatai;

- geriau įtvirtinamos žinias;

- gaunamas platesnis suvokimas apie dalykų sąsajas praktikoje;

- atsiskledžiamos praktinio pritaikymo galimybès;

- ugdomas studentų sisteminis mąstymas;

- geriau įsisavinamama pateikta medžiaga;

- racionaliau panaudojamas laikas;

- ugdomas kūrybiškumas.

Taigi, tyrimas atskleidè dar daugiau integruoto mokymo privalumų, taikant ji arba ruošiantis taikyti IB veikloje.

Sukonkretinant, kokiuose IB veiklos skyriuose jau yra esama ir/ar galima dalyko integracija, respondentų buvo užklausta, kokiuose IB skyriuose esama ir/ar galima Jūsų dalyko integracija? (5 pav.). Nuo 20 iki 26 proc. respondentų atsakè, kad jau dabar integruoja savo dèstomus/mokomus dalykus į IB veiklą nuo 74 iki 80 proc. mano, kad jų dèstomo/mokomo dalyko integracija ị IB esančius skyrius tikrai būtų galima. Tyrimas atskleidè, kad 80 proc. respondentų galètų integruoti savo dèstomą/mokomą dalyką ị IB Finansų skyriaus (mokesčiai ir jų paskaičiavimas; mokesčių apskaita; atlyginimų apskaita) veiklą, 78 proc. ị IB Rinkodaros skyriaus veiklą (rinkos tyrimų organizavimas; vartotojų poreikių nustatymas; konkurentų analizė; bendrovès naujo produkto kūrimas; rèmimas, kainodara; naujausių informacinių technologijų panaudojimas organizuojant pardavimus: 
e-parduotuvè, internetas, e-paštas; spausdintinès reklamos rengimas: katalogai, lankstinukai, skrajutès, vizitinès kortelés; pasirengimas ir dalyvavimas mugėse; mugès rezultatų analizé; dokumentu tvarkymas, ataskaitų rengimas, anketų pildymas).

Finansų skyrius (mokesčiai ir jų paskaičiavimas; mokesčių apskaita; atlyginimų apskaita.)

Rinkodaros skyrius (rinkos tyrimụ organizavimas; vartotoju poreikių nustatymas; konkurentı̨ analize; bendrovés naujo produkto kūrimas; rèmimas, kainodara; naujausių informaciniu technologijų panaudojimas organizuojant pardavimus: Eparduotuve, internetas,

Pirkimų -pardavimų skyrius (tiekejų paieška ir atranka; pirkimo - pardavimo sutarčił sudarymas; Pirkimo pardavimo dokumentų pildymas).

Personalo skyrius (prièmimo ị darbą organizavimas; informacijos paieška ir atranka; susirašinèjimas su kitomis institucij omis planı̨ ir ataskaitų rengimas; derybų, susirinkimų, pasitarimų organizavimas; darbuotojų ịtraukimas ị val dymą; sprendimu prièmimas;

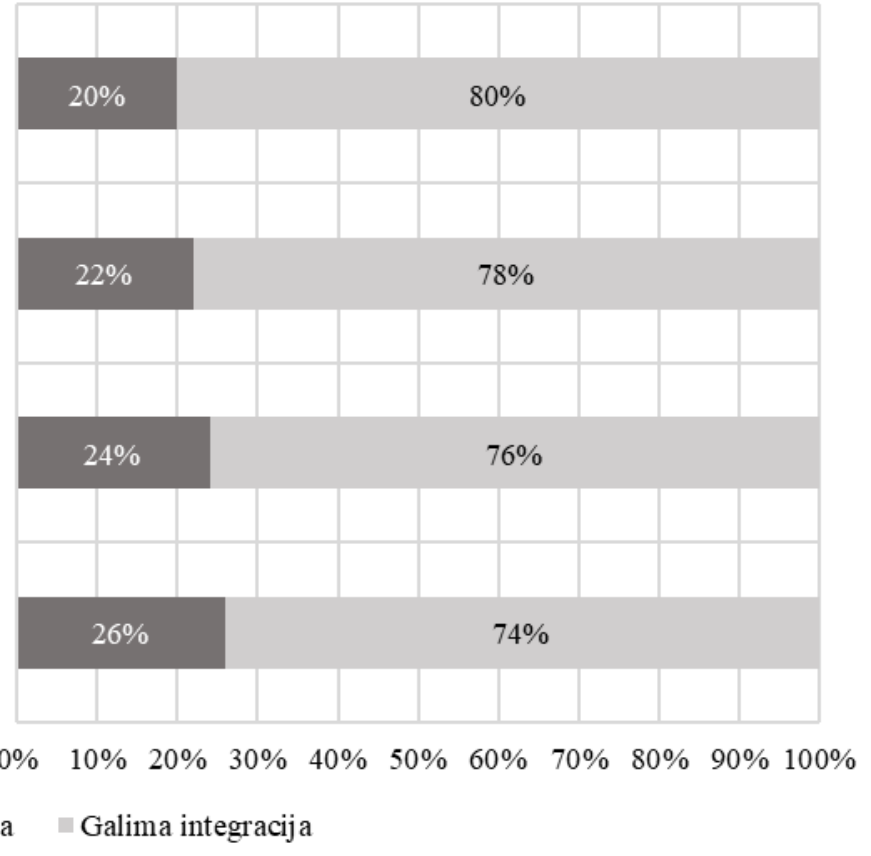

Esama integracija Galima integracija

5 pav. IB skyriai, kuriuose esama ir/ar galima respondentų dèstomo/mokomo dalyko integracija, proc. Šaltinis: sudaryta autorių pagal tyrimo duomenis, 2020

76 proc. ị IB Pirkimų - pardavimų skyriaus veiklą (tiekejjų paieška ir atranka; pirkimo pardavimo sutarčiu sudarymas; Pirkimo pardavimo dokumentų pildymas). 74 proc. i IB Personalo skyriaus veiklą (prièmimo ị darbą organizavimas; informacijos paieška ir atranka; susirašinejjimas su kitomis institucijomis planų ir ataskaitų rengimas; derybų, susirinkimų, pasitarimų organizavimas; darbuotojų ịtraukimas ị valdymą; sprendimų prièmimas; komandinio darbo organizavimas; konfliktų valdymas; darbuotojų atestavimas ir vertinimas).

Tyrimo metu buvo siekta išsiaiškinti, kokiais būdais būtų galima padidinti verslumo igūdžių ugdymo efektyvumą, todèl respondentams buvo pateiktas klausimas - İvertinkite, kurie būdai didintinų verslumo igūdžių efektyvumą IB, taikant Jūsų dèstomo/ mokomo dalyko integraciją? Ivertinkite kiekvieną atsakymą nuo 1 iki 5, kai 1 - visiškai nepritariu, 5 - visiškai pritariu (6 pav.).

Studentų/moksleivių ịtraukimas ị darbdavių ir socialinių partnerių ịmonių aktualių problemų sprendimus.

Darbdavių ir socialinių partnerių ịtraukimas ị programı̨ atnaujinimo, metodinès medžiagos ir praktinių užduočių rengimo procesą.

Déstytoj Ł̨/mokytojų tarpusavio bendradarbiavimas, rengiant metodinę medžiagą ir bendras praktines užduotis.

Déstytojų/mokytojų tarpusavio bendradarbiavimas, atnaujinant studiju programas.

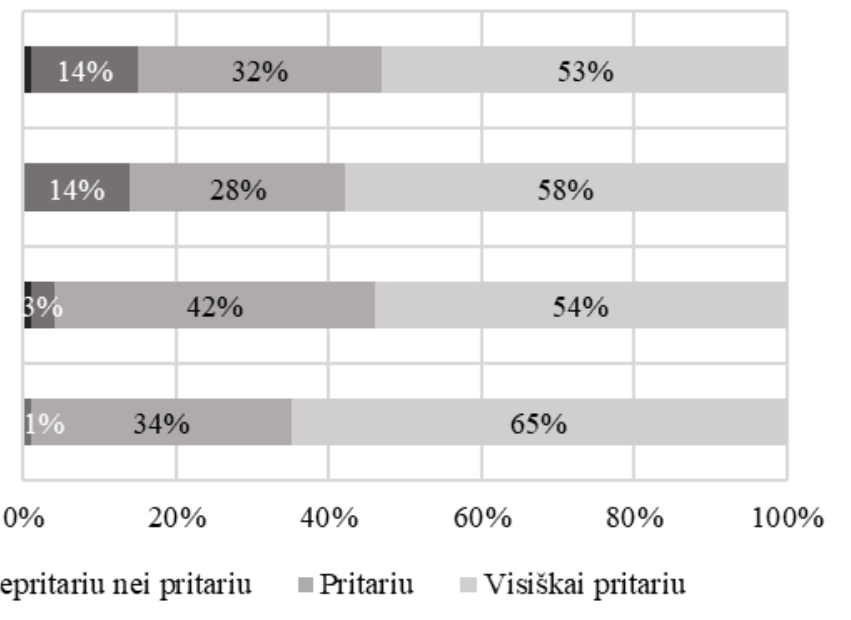

- Visiškai nepritariu

- Nepritariu

- Nei nepritariu nei pritariu

6 pav. Verslumo ịgūdžių efektyvumo didinimo būdai IB, taikant dèstomo/ mokomo dalyko integraciją, proc.

Šaltinis: sudaryta autorių pagal tyrimo duomenis, 2020. 
Dauguma respondentų 99 proc. pritarè arba visiškai pritarė dėstytojų/ mokytojų tarpusavio bendradarbiavimui, atnaujinant studijų programas; 97 proc. pritaré teiginiui dėstytojų/mokytojų tarpusavio bendradarbiavimui, rengiant metodinę medžiagą ir bendras praktines užduotis; 86 proc. pritarė arba visiškai pritare darbdavių ir socialinių partnerių įtraukimą i programų atnaujinimo, metodinès medžiagos ir praktinių užduočių rengimo procesą; 85 proc. - studentų/moksleivių įtraukimą ị darbdavių ir socialinių partnerių ịmonių aktualių problemų sprendimus.

Tyrimo metu, siekiant išsiaiškinti respondentų nuomonę, apie tai, kokie dar būdai jų nuomone didintų verslumo ịgūdžių efektyvumą IB, taikant jų dėstomo/mokomo dalyko integraciją, sulaukta sekančių pasidalinimų:

- bendras praktinių užduočių rengimas ir atlikimas;

- skirtingų švietimo įstaigų IB vadovų bendradarbiavimas;

- apsilankymas tikrose verslo įmonėse;

- verslo pasaulio atstovų dalyvavimas paskaitose/pamokose;

- integruotų dienų organizavimas ir apsilankymas kitose IB.

Apibendrinant tyrimo rezultatus galima teigti, kad IB veikla apima labai platų igytų teoriniu žinių pritaikomumą praktinèje veikloje, todèl integruojant dalykus integruotu mokymo lygiu rengiant bendras praktines užduotis, būtų aiškesnès tarpdalykinių ryšių sąsajos. Integruotas mokymas skatintų dėstytojų/ mokytojų tarpusavio ir studentų/mokinių bendradarbiavimą, ugdytų komunikavimo ir komandinio darbo igūdžius. Integracija pagilina, išplečia, susieja žinias ir gebejjimus bei skatina kūrybiškumą, padeda kuo efektyviau padèti studentui/mokiniui ịsisavinti sudètingą mokymo turinị, giliau įsisavinamos žinios, ugdomas sisteminis mąstymas ir atsiskleidžiamos praktinio pritaikomumo galimybès.

\section{Išvados}

1. Remiantis literatūros šaltinių analize, atskleista integruoto ugdymo nauda, leidžianti sisteminti informaciją, sieti ją su praktine veikla, didinanti besimokančiųu motyvaciją, skatina besimokančiujų ir dèstytojų/mokytojų bendradarbiavimą. Integracija apima visapusišką asmenybès ugdymą ir integruotą mokymą(si), kurio metu panaudojamos skirtingų dalykų žinios, ịvairiais aspektais susijusios su besimokančiojo aplinka. Pagal integruojamų dalykų ryšių sudètingumą išskiriami jungimo, koreliacijos ir integruoto mokymo bei projektinio integruoto ugdymo lygiai.

2. Išanalizavus dalykų integravimo galimybes ị IB veiklą, nustatyta, kad dauguma respondentų atsakè, kad jų galima dėstomo/mokomo dalyko integracija ị IB veiklą integruotųsi integruotu mokymo lygiu, kai pasirenkama tema apima visas arba daugeli disciplinų. IB veikla apima labai platų igytų teorinių žinių pritaikomumą praktinejje veikloje, todèl integruojant dalykus integruotu mokymo lygiu rengiant bendras praktines užduotis, būtų aiškesnès tarpdalykinių ryšių sąsajos.

3. Dėstytojai/mokytojai, vertindami integruotų dalykų privalumus i IB veiklą, pabrèžia, kad integruotos paskaitos/pamokos paivvairina ugdymo procesą, jos įdomesnès, skatinančios savarankišką mokymąsi, kelia studentų /mokinių mokymosi motyvaciją; integruotas mokymas skatina desstytojų/ mokytojų tarpusavio ir studentų/mokinių bendradarbiavimą, ugdo komunikavimo ir komandinio darbo igūdžius; integracija pagilina, išplečia, susieja žinias ir gebejjimus bei skatina kūrybiškumą; integracija padeda kuo efektyviau padèti studentui/mokiniui įsisavinti sudètingą mokymo turinį, giliau ịsisavinamos žinios, ugdomas sisteminis mąstymas ir atsiskleidžia praktinio pritaikomumo galimybès.

4. Analizuojant verslumo ugdymo efektyvumo didinimo būdus, taikant dalykų integravimą IB veikloje, buvo išsiaiškinta, kad reikètų skatinti dėstytojų/ mokytojų tarpusavio bendradarbiavimą, atnaujinant studijų programas, rengiant metodinę medžiagą ir bendras praktines užduotis, reikètų įtraukti darbdavius ir socialinius partnerius, lankytis tikrose verslo įmonèse ar kviesti verslo atstovus ị paskaitas/pamokas ir nagrinèti praktines situacijas. Būtų galima pasiūlyti mokymo institucijose kurti bendrą su kitais dalykais integruotą virtualią aplinką, kurioje būtų pateikiama metodinè medžiaga, integruotos užduotys, bendradarbiavimo ir vertinimo priemonių sistema, 
leidžianti lanksčiai valdyti integruotą studijų procesą, siekiant gerinti mokymosi kokybę, orientuotą i platesnị žinių panaudojimą.

\section{Literatūra}

1. Bakonis, E. (2018). Integruoto ugdymo galimybès. Prieiga per internetą: https://www.svietimonaujienos.lt/integruoto-ugdymo-galimybes/

2. Bitinas, B., Rupšienè, L., Žydžiūnaitè, V. (2008). Edukologinis tyrimas: sistema ir procesas. Kronta, Vilnius.

3. Danilevičiūtè, A., Kančialskytè, A., Preidys, S., Rutkauskienė, D., Targamadzė, A.,Trinkūnas, V., Ulinskaitè, D. (2014). Metodine medžiaga: Elektroninio mokymo taikymas. Prieiga per internetą: http://www.esparama.lt/es parama pletra/failai/ESFproduktai/2014 E mokymo taikymas.pd:f

4. Drake, S., Burns, R. (2010). Meeting Standarts Through Integrated Curriculum. Association for Supervision and Curriculum Development Alexandria, Virginia USA.

5. Gaižauskienė, I., Valavičienė, N. (2016). Socialiniu tyrimu metodai: kokybinis interviu. Vilnius: viešoji įmonè Registrų centras.

6. Geoff, P. (2006). Šiuolaikinis mokymas: praktinis vadovas. Vilnius: Tyto alba.

7. Junevicius, A., Juneviciene, O., Cepeliauskaite,G., Daugeliene, R. (2021). Development and Implementation of Integrated Curriculum in Management Studies: European Journal of Contemporary Education (ejournal1.com)

8. Junevičienè, O. (2011) Kaip spręsti integruotas užduotis. Kaunas.

9. Kardelis, K. (2009). Moksliniu tyrimu metodologija ir metodai. Judex, Kaunas.

10. Kaulakienè, A., Keinys S. (2013). Tarptautinių žodžių žodynas. Vilnius: Alma littera.

11. Kiliuvienė, D. (2002). Integruotojo mokymo didaktiniai aspektai. Pedagogika.

12. Lietuvos imitacinių bendrovių asociacija LIBA. Prieiga per internetą: http://sl.viko.lt/liba/

13. PEN Worldwide. Prieiga per internetą: https://www.penworldwide.org/get-to-know-ourassociation/

14. Simulith centras. Prieiga per internetą: http://sl.viko.lt/

15. Snyder, S. (1996). Integrate with Integrity. Art Education.

16. Valackienè, A., Mikènè, S. (2008). Sociologinis tyrimas. Metodologija ir atlikimo metodika. Technologija, Kaunas.

17. Vilkelienè, A. (2006). Integruotas ugdymas: disciplinu integralumas nūdienos kontekste. Vilnius.

\section{INCREASING EFFICIENCY OF ENTREPRENEURSHIP EDUCATION IN SIMULATION COMPANIES THROUGH SUBJECT INTEGRATION}

Asta Pancerovienė, Adelė Stonienė, Vida Žvinienė

Klaipeda State University of Applied Sciences

Summary

Today curricula integration is becoming an increasingly important phenomenon in the process of education system change. Integrated education makes sense when subjects are integrated taking into account the multifaceted structure of the intellect and the integrity of subjects. In 2021, research commissioned by the Lithuanian Association of Imitation Companies was completed, the aim of which was to reveal the possibilities of efficiency increase of entrepreneurship education in imitation companies by applying subjects integration.

During the research, it was decided to interview IB managers and lecturers/ teachers working in those study programs where IBs are active. The aim was to interview 84 respondents and the answers were received from 81 respondent.

The research was carried out in 2019-2021. In 2019, a research questionnaire, research methodology, research calendar were prepared.

Given that, there was insufficient number of respondents, the survey has been extended through the period of September-November, 2020. The results of the research were analyzed and a research report was prepared during January March, 2021. The research method used is a questionnaire survey using a pre-prepared standardized questionnaire designed by the authors of the research. The questionnaire consisted of demographic questions and statements aimed at assessment the possibilities of subject integration in developing entrepreneurship competences in simulation companies. 
Based on the analysis of literature review, the benefits of integrated education have been revealed, allowing to systematize information, linking it with practical activities, increasing learners' motivation, encouraging cooperation between learners and teachers. Integration includes comprehensive personality development and integrated teaching/ learning, which uses knowledge of different subjects in various aspects related to the learner's environment. According to the complexity of the connections of the integrated subjects, the levels of connection, correlation and integrated teaching and project integrated education are distinguished.

After analyzing the possibilities of subject integration into IB activities, it was found that the majority of respondents answered that possible integration of the taught subject into IB activities would be integrated at an integrated teaching level, when the chosen topic covers all or many disciplines. IB's activities cover a very wide range of theoretical knowledge application in practice, so subject integration at an integrated teaching level into common practical tasks would lead to clearer interdisciplinary links. Teachers, evaluating the advantages of subject integration in IB activities, emphasize that integrated lectures/ lessons diversify the educational process, they are more interesting, promote independent learning, increase students' learning motivation; integrated teaching promotes cooperation between teachers and students, develops communication and teamwork skills; integration deepens, expands, links knowledge and skills and fosters creativity; it also helps the student to master the complex curriculum as effectively as possible, deepens the acquisition of knowledge, develops systematic thinking and reveals the possibilities of practical applicability.

The analysis of ways to increase entrepreneurship education efficiency through the subject integration in IB activities revealed that collaboration between teachers should be encouraged during update of study programs, development of methodological materials and common practical tasks, employers and social partners should be involved in the process, real businesses should be visited or business representatives invited to lectures/ lessons and practical situations examined. It is proposed to create a shared virtual environment with other integrated study subjects, which would provide methodological material, integrated tasks, a system of cooperation and assessment tools, allowing flexible management of the integrated study process to improve the quality of learning focused on wider use of knowledge.

Keywords: entrepreneurship, imitation company, integration of study subjects. 